\title{
The epidemiological profile of patients attended by the public physiotherapy service in the city of Boa Vista do Cadeado, RS
}

\author{
O perfil epidemiológico dos pacientes atendidos pelo serviço \\ público de fisioterapia no município de Boa Vista do Cadeado, RS
}

\section{Karine Thaís Funck, Patricia Steinner Estivalet*}

Universidade Feevale (Feevale), Novo Hamburgo, RS, Brazil

\begin{abstract}
Introduction: To understand the role of physiotherapy in Brazilian society, to know its responsibilities and challenges, is necessary to know the epidemiological profile of the population. Objective: The objective of this study was to identify the epidemiological profile of the patients treated by physiotherapy public service in Boa Vista Cadeado, RS. Materials and methods: This is a quantitative study of the descriptive retrospective epidemiological sort through the technical procedure of documentary research, through the analysis of evaluation sheets of all patients attended at the physiotherapy sector in the period of 2004 to 2011. Results: 623 records were analyzed by means of variables such as gender, age and pathology. The study showed that the population attended is mostly composed by female patients, aged between 51 and 60 years old in the treatment of skeletal muscle disorders predominantly related to the spine. Conclusion: We concluded that it is necessary to know the population as for its etiologic factors
\end{abstract}

* KTF: Specialist, e-mail: kakafunck@yahoo.com.br PSE: MSc, e-mail: patriciae@feevale.br 
of pathologies for the elaboration of primary care strategies to health, aiming health promotion, disease prevention and quality of life.

Keywords: Epidemiological profile. Physiotherapy. Skeletal muscle disorders.

\section{Resumo}

Introdução: Para entender o papel da fisioterapia na sociedade brasileira, saber suas responsabilidades e seus desafios, é necessário conhecer o perfil epidemiológico da população. Objetivo: O objetivo deste estudo foi identificar o perfil epidemiológico dos pacientes atendidos pelo serviço público de fisioterapia no município de Boa Vista do Cadeado, RS. Materiais e métodos: Trata-se de um estudo quantitativo do tipo epidemiológico retrospectivo descritivo, através do procedimento técnico de uma pesquisa documental, por meio da análise das fichas de avaliação de todos os pacientes atendidos no setor de fisioterapia, no período de 2004 a 2011. Resultados: Foram analisados 623 prontuários, através das variáveis estudadas, como sexo, faixa etária e patologia. 0 estudo demonstrou que a população atendida é em sua maioria composta de pacientes do sexo feminino, com faixa etária entre 51 e 60 anos, em tratamento de patologias relacionadas a distúrbios musculoesqueléticos predominantemente ligados à coluna vertebral. Conclusão: Concluiu-se que é preciso conhecer a população quanto aos fatores etiológicos das patologias, para elaboração de estratégias de atenção primária à saúde, objetivando a promoção à saúde, a prevenção de doenças e a qualidade de vida.

Palavras-chave: Perfil epidemiológico. Fisioterapia. Distúrbios musculoesqueléticos.

\section{Introduction}

To understand the role of physiotherapy in the Brazilian society, to know its responsibilities and challenges, it is necessary to know the epidemiological profile of the population (1). It allows a change in the action profile by intervening directly with the care processes and attending the current needs of health services.

However, the profile of a population comes from the identification of the risk factors to which it is exposed (2), which, in turn, will determine the actions of health promotion, disease prevention, health education and the construction of the treatment plan to be proposed for each patient.

Hence, it is extremely important to know the attended patients' profile in a given population, identifying who is the user of the physiotherapy service, what is the demand of the service, which diseases affect him and what are the implications and complications of the user's pathological or traumatic condition, mainly as skeletal muscle disorders. And through this knowledge, it is possible to build and plan a proper and specific assistance that addresses the patient's needs and respect his peculiarities, thus ensuring a better care (2).
In addition, this research points population's characteristics that will be able to serve as a parameter for the city to critically assess how the physiotherapy service is organized, what can be done to an improvement in the care for the implantation of more appropriate services, a wider multidisciplinary interaction, and future investments in the sector, in order to provide a more comprehensive care to this population.

However, for an intervention program to get the wished effectiveness, it is necessary that the professional knows which diseases that are affecting the population, about their multiple determinants, which is the raw material from which it is possible to derive behaviors capable to generate preventive interventions about these problems (3).

It is also the physiotherapist, along with the health team, who plans and develops strategies covering both the rehabilitation actions, which cannot fail to be developed, and the actions of health promotion and disease prevention, constituting a new force for the transformation of the social and epidemiological reality.

Buss (4) highlights that it is in the movement of healthy municipalities that such strategies are consolidated, through their own foundations and practices, which are closely related to the innovations in 
public health for the integrated and sustainable local development.

Finally, it is expected that the physiotherapist, as a health professional inserted in the public service, identifies and evaluates the population's needs and characteristics, having a critical view related to the prevailing health policies (2).

Therefore, this proposed action and organization of physiotherapy in Boa Vista do Cadeado, can bring benefits to the population, keeping it healthy through the prevention and improving more its quality of life. Thus the author Tabosa points out (2) the importance of the therapist's work with patients in basic attention and its presence in the daily life of health centers.

Therefore, this study was outlined up with the objectives of identifying the epidemiological profile of patients treated by physiotherapy public service in the city of Boa Vista do Cadeado-RS, checking how many people were attended from 2004 to 2011 and what are the main pathologies treated, mainly about the skeletical-muscle disorders, ponting out this way the population characteristics.

\section{Methods and materials}

This research is presented under a quantitative paradigm from the descriptive retrospective epidemiological sort, through the technical procedure of documentary research, because it was carried out by analyzing the evaluation records of patients seen in the physiotherapy sector of the mentioned city, not having, therefore, any contact with the patients.

The data was obtained through the gathering and analysis of medical records from the public physiotherapy sector in Boa Vista do Cadeado, in the period of 2004 to 2011.

With regard to ethical issues, the research was guided by the guidelines recommended by Resolution n.196/96 of the National Health Council, and the project was submitted to the Ethics and Research Committee of Feevale University and approved under the CAAE number 07023612.6.0000.5348.

The data collection was made in the physiotherapy sector of the city, through the patient's evaluation sheet, composed by the identification data, and the variables studied were consisted by the patient's age, gender and condition, and was held in October 2012, with the help of the physiotherapist responsible for the care in the public service.
Thus, the data was stored in a database developed in a spreadsheet of Microsoft Office Excel 2007 program and in Microsoft Office Word 2007 files and analyzed by descriptive statistical methods, using charts and graphics.

\section{Results}

In the present study, 623 medical records of the patients who were treated in the physiotherapy sector of the city were analyzed, through the studied variables such as gender, age and pathology.

According to the results, it can be seen that 379 (61\%) patients were female, and 244 (39\%) were male.

The results also showed that 183 (29\%) patients who searched for treatment or who were sent there are between 51 and 60 years old, $173(28 \%)$ patients are in the age group of 41 to 50 years old, $124(20 \%)$ patients who are 61-70 years old and 74 (12\%) patients are between 31 and 40 years old.

The Table 1 shows the main pathologies treated in the physiotherapy service, revealing that $76(12 \%)$ patients have marginal osteophytes in the lumbosacral spine, 62 (10\%) patients with degenerative disc disease in the lumbosacral spine, $51(8 \%)$ patients have tendinopathy problem in the shoulder $38(6 \%)$ with marginal osteophytes in the lumbar spine, 28 (4\%) with shoulder bursitis, 27 (4\%) present degenerative disc disease in the cervical spine, 21 (3\%) have arthrosis in the shoulder, $21(3 \%)$ herniated disc in the lumbosacral spine, 18 (3\%) epicondylitis, 17 (3\%) with degenerative disc disease in the cervical spine, 17 (3\%) arthrosis in the cervical spine, 16 (3\%) with herniated disc in the lumbar spine and 103 (16\%) patients presented other diseases.

It is important to note that the same patient can present more than one pathology.

As for the treatment area with the highest prevalence, it was the skeletal muscle disorders with 612 (98\%), and only $11(2 \%)$ in the neurological field.

\section{Discussion}

Given the results obtained and analyzed, and according to the pre-established goals, the study about the epidemiological profile of the patients treated at the public physiotherapy sector in Boa Vista do 
Cadeado showed that the population attended there is mostly composed by female patients, aged between 51 and 60 years old in treatment of pathologies related to skeletal muscle disorders predominantly related to the spine.
This data is possibly related to the rural labor activity of patients who do a blue-collar labour even with agricultural machinery, because the city has the economy based on livestock and agriculture, through the cultivation of soybeans, corn and wheat.

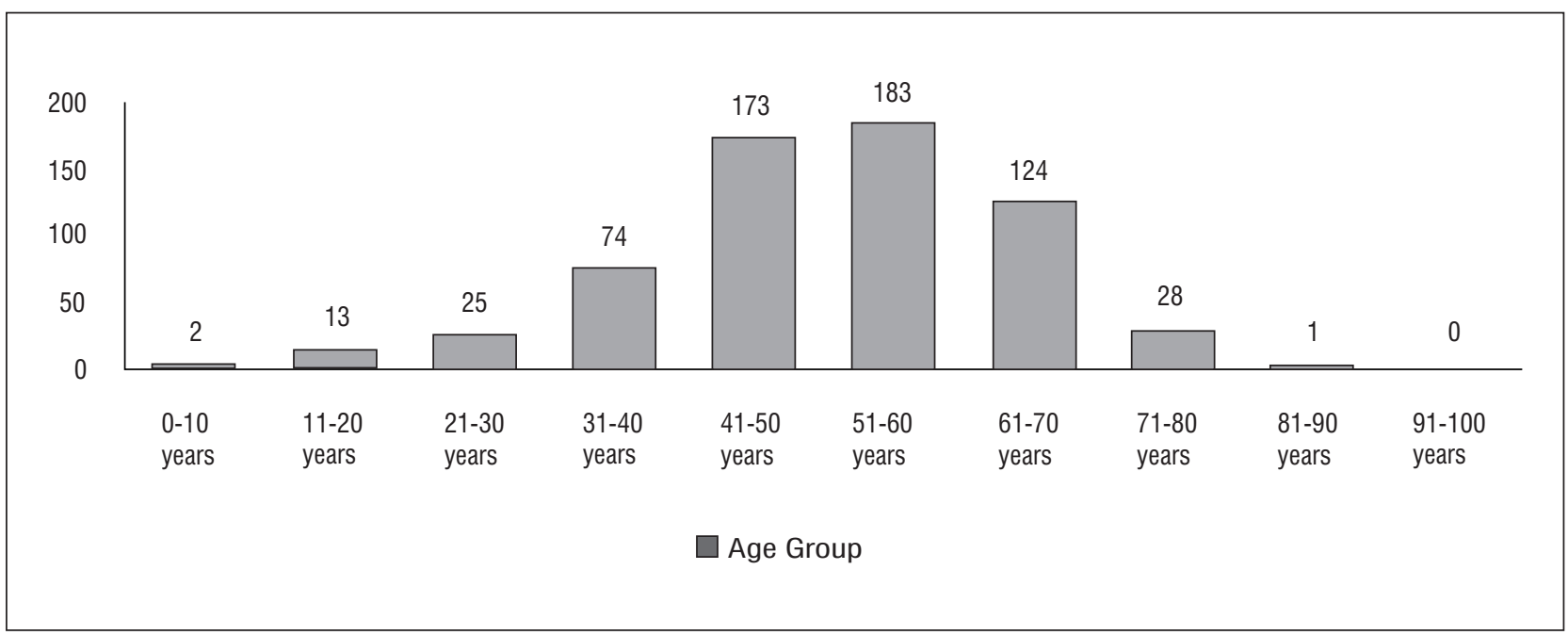

Figure 1 - Occurrence, by age group, of patients treated in the public physiotherapy sector in Boa Vista do Cadeado, RS

Table 1 - Main pathologies treated in the physiotherapy public sector in Boa Vista do Cadeado city - Rio Grande do Sul state

(to be continued)

\begin{tabular}{lll}
\hline Pathologies & N & $\%$ \\
\hline Marginal ostheophytes in the lumbosacral spine & 76 & $12 \%$ \\
Degenerative disc disease in the lumbosacral spine & 62 & $10 \%$ \\
Tendinopathy in the shoulder & 51 & $8 \%$ \\
Marginal Osteophytes in the lumbar spine & 38 & $6 \%$ \\
Shoulder bursitis & 28 & $4 \%$ \\
Degenerative Disc Disease in the cervical spine & 27 & $4 \%$ \\
Shoulder Arthrosis & 21 & $3 \%$ \\
Herniated Disc in the lumbosacral spine & 21 & $3 \%$ \\
Epicondylitis & 18 & $3 \%$ \\
Degenerative Disc Disease in the lumbar spine & 17 & $3 \%$ \\
Arthrosis in the cervical spine & 17 & $3 \%$ \\
Disc herniation in the lumbar spine & 16 & $3 \%$ \\
Lumbar scoliosis & 14 & $2 \%$ \\
Arthritis in the knee & 13 & $2 \%$ \\
Osteopenia in the lumbosacral spine & 9 & $1 \%$
\end{tabular}


Table 1 - Main pathologies treated in the physiotherapy public sector in Boa Vista do Cadeado city - Rio Grande do Sul state

\begin{tabular}{lll} 
& & (conclusion) \\
\hline Pathologies & $\mathbf{N}$ & $\%$ \\
\hline Spondilolisthesis in the lumbosacral spine & 9 & $1 \%$ \\
Heel spur & 9 & $1 \%$ \\
Stroke & 7 & $1 \%$ \\
Complete rupture of the supraspinatus & 6 & $1 \%$ \\
Osteoporosis in the lumbosacral spine & 6 & $1 \%$ \\
Marginal Osteophytes in the dorsal column & 6 & $1 \%$ \\
Partial rupture of the supraspinatus & 5 & $1 \%$ \\
Spondylosis in the lumbosacral spine & 5 & $1 \%$ \\
Lumbosacral scoliosis & 5 & $1 \%$ \\
Osteoporosis in the cervical spine & 5 & $1 \%$ \\
Arthrosis in the hip & 5 & $1 \%$ \\
Patellar osteophytes & 4 & $1 \%$ \\
Degenerative disc desease in the spine & 4 & $1 \%$ \\
Dorsal scoliosis & 4 & $1 \%$ \\
Spondylolisthesis in the lumbar spine & 4 & $1 \%$ \\
Carpal tunnel syndrome & 4 & $1 \%$ \\
Radius Fracture & 4 & $1 \%$ \\
Other pathologies & 4 & $1 \%$ \\
Total & 4 & \\
\hline
\end{tabular}

Note: $\mathrm{n}=$ total number of individuals; $\%$ = Relative frequency.

According to the census referred to the year of 2010 , the city of Boa Vista do Cadeado has a population of 2,441 inhabitants, which 1,257 are males and 1,184 females, and the age group with the highest prevalence are women from 40 to 44 years old (5).

In this study, the rates found are similar to those found by other authors $(2,6,7,8,9,10)$, who observed in their research that the female gender was the most affected, and the area of musculoskeletal disorders had higher prevalence.

Avolio (11) found in his survey made with the population enrolled in ESFs of the city of Cabo Frio, $\mathrm{RJ}$, that the age group with the highest prevalence was over 60 years old, and that $33 \%$ of the problems come from the stroke sequels and from the spine, followed by the physiopathologies originated from traffic accidents with $23 \%$ and $7 \%$ by trauma in general.

In the study made by Jesus (12), about the profile of patients undergoing physical therapy in the clinic school of IBES College, it was noted that most of the patients was between 16 and 59 years old, representing $56.18 \%$ of the total sample, with prevalence of female patients, with $57.25 \%$. As for clinical diagnosis in orthopaedics area, $25(16.77 \%)$ patients were observed with gonarthrosis, 11 (7.38\%) with lumbar herniated disc, 8 ( 5.36\%) with neck pain, 7 (4.69\%) at the lumbar spine spondyloarthritis 6 (4.02\%) with Low Back Pain, 5 (3.35\%) with carpal tunnel syndrome, 5 (3.35 \%) with wrist fracture, 4 (2.68\%) with bursitis, 4 (2.68\%) with shoulder tendinitis, 4 
(2.68\%) with De Quervain's stenosing tenosynovitis and $70(46.97 \%)$ patients with other diagnosis.

Nogueira et al. (13) observed their research on the epidemiology profile of the physiotherapy clinic of a university hospital, the average age of 54.5 years old, predominantly between 41 and 70 years, the gender that prevailed was the female, with $77.5 \%$, the main affected region was the spine, predominating the medical care in skeletal muscle conditions.

Women present a greater risk than men for pain in the spine. This risk was expected, considering that women increasingly reconcile performing housework with work outside home, where they are exposed to overloads, mainly repeatability, vicious positions and work at high speed. In addition, females have some anatomical features such as smaller stature, smaller muscle mass, lower bone mass, more fragile joints and less adapted to heavy physical exertion and greater weight of fat, which can contribute to the emergence of pain $(14,15)$.

The World Health Organization says that $80 \%$ of the population suffers from backache, most of times, the wrong posture is the major cause of this harm. Spine problems are the main causes of clearance work, even if the profession does not cause impact to the region, the spine ends up being the victim of habits that harm it (16).

And according to the health ministry, up to $70 \%$ of people over 40 have some problem in the spine and this number rises to about $90 \%$ in the population above 50 years old (16).

Through these results, it is possible to strengthen the idea of the physiotherapist's work such as prevention and rehabilitation, being able to see the human being in a full way and being aware of his social responsibility.

It is noticed that the physiotherapist professional has the potential to work creatively and develop efficient and effective actions in the family health according to the community needs (17).

Hence the health situation of the population of each society, in general, is closely related to its living conditions and the processes that transform it. Thus, public health, in its optimal performance, must try to identify these processes and organize more effective and efficient ways of acting on the determinants and conditions of the health situation in order to improve health and quality of life of individuals and of the population (18).
These actions focused on the development of activities in education and health in the communities and activities in the health of children, women, adult and elderly, also covering the care of patients confined to bed / home, at different levels of complexity from SUS is a great challenge posed to education, service and management. The search for the prevention of increased volume and complexity of attention avoiding the increase of diseases while limiting the damage already installed, consolidates the current trend of professional practice (19).

Thus, most of the activities developed by the physiotherapist is the sum of caring about the user, where systematized and humanized assistance ensures the quality of care. The professional has also the function of managing the assistance, plan and program the health education actions directed to the population, as well as interact with the team that makes up the list of workers in the health sector (20).

Thereby, the planned inclusion, officialized and articulated with the physiotherapist's multidisciplinary team along with the Family Health Program, would surely bring benefits to both the FHP itself as for the general population, increasing the resolution and the completeness of health care, contributing for the improvement of health services and the population would have in fact a capable service to contribute to the prevention, treatment and especially in the rehabilitation of various pathologies (21).

Rodriguez (22) points out that this intervention does not depend only on the performance of a professional, but on the flexibility of the social actors involved, which will show a physiotherapist even more capable to act with a sense of responsibility, recognizing as a social change agent in defense comprehensive health, committed to citizenship and aware of the nature of the health problems in their relations with the context.

\section{Conclusion}

There was a significant predominance of female patients of appointments, aged between 51 and 60 years old in the treatment of pathologies related to skeletal muscle disorders, in which the main region affected was the spine.

It was concluded that given the results of this study, it is firstly necessary to know the population 
with regard to etiologic factors of pathologies for the elaboration of primary care strategies to health, aiming the health promotion, disease prevention and quality of life. This way, the physiotherapeutic approach could be carried out to avoid possible injuries originated from the activity of the worker's daily life, through lectures for the individual, for the family and for the community regarding self-care, functional disabilities and pathophysiological processes.

Once through the improvement of the population's quality of life, through the implementation of actions that enable citizens to know, try and incorporate regular physical activity, the users' practices are defined.

This proposal can bring benefits to the population, in the sense of health maintenance and / or controlling the major part of pathologies susceptible to accompaniment by the physiotherapist.

\section{References}

1. Júnior JPB. Fisioterapia e saúde coletiva: desafios e novas responsabilidades profissionais. Cien Saude Colet: Vitória da Conquista. 2010;15 Suppl 1:1627-36.

2. Tabosa ICM. Perfil dos pacientes em tratamento na clínica pública de fisioterapia de uma cidade no interior de Pernambuco [abstract]. In: XIX Congresso Brasileiro de Fisioterapia, 2011, Florianópolis. Palmares (PE): Instituição Secretaria Municipal de Saúde do Município de Palmares-PE; 2011;1-6.

3. De Vitta A. Atuação preventiva em fisioterapia. Bauru SP: EDUSC. 1999.

4. Buss PM. Promoção da saúde e qualidade de vida. Cien Saude Colet: Rio de Janeiro. 2000; 5(1): 163-77.

5. IBGE: Instituto Brasileiro de Geografia e Estatística. Brazil. 2010. Available from: www.ibge.gov.br/ censo2010/

6. Watanabe LA. Perfil epidemiológico dos pacientes atendidos no setor de fisioterapia de uma clínica de ortopedia em Goiânia [monography]. São Marcos, GO: Universidade São Marcos; 2012.

7. Oliveira AC, Braga DLC. Perfil epidemiológico dos pacientes atendidos na clínica de ortopedia da Universidade Paulista. J Health Sci Inst: São Paulo. 2010; 28(4):356-8.
8. Menegazzo IR, Pereira MR, Villalba JP. Levantamento epidemiológico de doenças relacionadas à fisioterapia em uma Unidade Básica de Saúde do município de Campinas. J Health Sci Inst: São Paulo. 2010; 28(4): 348-51.

9. Martinez JE. Perfil clínico e demográfico dos pacientes com dor musculoesquelética crônica acompanhados nos três níveis de atendimento de saúde de Sorocaba. Revista Acta Fisiatr: São Paulo. 2004;(2):67-71.

10. Santos FAS, et al. Perfil epidemiológico dos atendidos pela fisioterapia no Programa Saúde e Reabilitação na Família em Camaragibe - PE. Revista Fisioterapia e Pesquisa. 2007;14(3):50-4.

11. Avolio GP. Fisioterapia no PSF: uma proposta de ação para o município de Cabo Frio, estado do Rio de Janeiro [dissertation]. Rio de Janeiro (RJ): Universidade Estácio de Sá; 2007.

12. Jesus EAS. Perfil dos pacientes sob tratamento fisioterapêutico na clínica escola da Faculdade IBES [article]. Salvador (BA): Faculdade IBES; 2009.

13. Nogueira LAC, et al. Perfil epidemiológico do ambulatório de fisioterapia de um hospital universitário. Revista Terapia Manual: Rio de Janeiro. 2011; 9(41):68-73.

14. Pivetta AD, et al. Prevalência de distúrbios osteomusculares relacionados ao trabalho em fisioterapeutas. Revista Digital. 2005 Jan; Ano X(80):1. Available from: www.efdeportes.com/

15. Silva MC, Fassa AG, Valle NCJ. Dor lombar crônica em uma população adulta do sul do Brasil: prevalência e fatores associados. Cadernos de Saúde Pública. 2004; 20(2):377-85.

16. Saiba já [Internet]. Dores na coluna: A postura errada pode ser a causadora desse mal. Matão (SP). 2012 Aug 21. Available from: www.saibaja.com.br/tv-matao/ noticia/540-dores-na-coluna

17. Paula RF, et al. Fisioterapia na comunidade: saúde da família, novos desafios e desenvolvimento das ações no trabalho multiprofissional. Revista Multidisciplinar Faculdades Integradas Pitágoras de Montes Claros. 2009 Feb;7(7):1-73.

18. Buss PM. Promoção da saúde da família. Revista Brasileira de Saúde da Família. 2002;2(6):50-63. 
19. Rodrigues RM. A fisioterapia no contexto da política de saúde no Brasil: aproximações e desafios. Revista Perspectivas online: Rio de Janeiro. 2008;2(8):104-9.

20. Almeida DCS, et al. A gerência na ótica do fisioterapeuta. Cascavel: Unioeste; 2005.

21. Castro SS, Cipriano Junior G, Martinho A. Fisioterapia no programa de saúde da família: uma revisão e discussões sobre a inclusão. Fisioterapia em Movimento: Curitiba. 2006 Oct-Dez; 19(4):55-62.
22. Rodriguez, MR. Análise histórica da trajetória profissional do fisioterapeuta até sua inserção nos núcleos de apoio a saúde da família (NASF). Com. Ciências Saúde: Brasília. 2010;21(3):261-6.

Received: 05/16/2013

Recebido: 16/05/2013

Approved: 05/12/2015

Aprovado: 12/05/2015 